\title{
Amateurism, Professionalism and the Value of College Sports
}

\author{
Heather L. Reid \\ Morningside University \\ Exedra Mediterranean Center
}

\section{Introduction}

The summer of 2021 seemed revolutionary for college sports. In NCAAv. Alston et al., the Supreme Court struck down limits on education-related benefits for college athletes, state laws went into effect permitting them to profit from their fame, and pay-for-play with standard employment benefits seemed just around the corner. All forms of media were abuzz with debate about the value of college sports. Behind today's legal, financial, and institutional questions, however, there are philosophical issues with roots running back to $535 \mathrm{BCE}$. That was the summer when the philosopher Pythagoras (known today for his theorem) walked into a gymnasium and marveled at the masterful ball-playing skills of a certain young athlete. Reasoning that such a performance demanded extraordinary virtues such as patience, persistence, courage, and self-control, the philosopher devised a scheme to educate him. Pythagoras offered to financially support the youth's athletic training in exchange for following the philosopher's lessons. The athlete agreed, and after some time, Pythagoras noticed that the athlete's motivation to study had shifted from the money to intellectual honor, so he cleverly announced that he would no longer be able to pay. The athlete offered to continue studying for free, but Pythagoras pled poverty, so the athlete, having developed a great passion for his studies, turned around and began paying the philosopher for the lessons (Iamblichus 300/1818, 5.21-24).

The ancient story has a happy ending, with the athlete Pythagoras recruited eventually writing his own books and travelling with his mentor to combine academic study with athletic exercise in gymnasia all over the ancient Greek world. The very term 'academic' derives from the gymnasium in Athens where Plato taught, following the examples of Pythagoras and his own teacher, Socrates. Education at the ancient Academy always included athletic activities - at least insofar as it remained true to Plato's idea that sport was an important tool for training the soul. ${ }^{1}$ The ancient Greeks combined athletics and academics in education to achieve arete (virtue, excellence), a disposition expected to lead to success in any profession. Somewhere 
along the line, however, this holistic idea of education fragmented. The term 'academics' came to designate worthwhile educational activities in contrast with 'athletics, ${ }^{2}$ the educational value of which — if it was recognized at all — was thought to be confined to the body (as evidenced by terms like 'physical education'). It comes as no surprise, then, that almost none of the ink spilled debating the college sports revolution of 2021 discusses its intrinsic educational value. Even the "education-related benefits" permitted in the Alston case refer specifically to non-athletic programs and awards. Nor should it come as a surprise that Myles Brand, a voice in the wilderness when it comes to articulating and defending the educational value of sport in the academy, was himself a philosopher.

Answers to the question "What is the value of college sport?" vary in form. For most, the answer is a number: the capital valuation of the industry (measured in billions of dollars), the revenue generated at a particular institution (usually measured in the millions), or even the dollar-valuation of an individual student's athletic scholarship package, which can exceed $\$ 100,000$ during their college career. Less-tangible and less-quantifiable benefits are less-often recognized: things like entertainment value, alumni engagement, state and community morale. Given that the college sport industry is, as Brand repeatedly pointed out, embedded within institutions whose mission is education, however, discussion and debate about its legal and financial issues should always take place in a context that prioritizes sport's educational value. A good understanding of the educational value of sport has the power to resolve the apparent oppositions between amateurism and professionalism, academics and athletics, even employment and exploitation. In this essay, I explore value of college sport from a philosophical point of view, attempting to clarify the concept of amateurism and paradoxically reveal its similarity to professionalism. I conclude that education is the value in college sport that needs to guide all the others-including those that involve dollar signs.

\section{Amateurism vs. Professionalism}

In the current debate about college sport, amateurism and professionalism are presented as opposites with the crucial distinction being pay. In the Alston case the National Collegiate Athletic Association (NCAA) argued that its limits on athlete compensation are needed to preserve the "amateur" nature of college sports, which widens consumer choice by providing a product distinct from professional sports (NCAA v. Alston, 2021, p. 10). They did not even attempt to deny the commercial nature of college sport, even as they argued that college athletes must not be professionals. This distinction reflects Brand's claim that in college sports, the term "“amateur' defines the participants, not the enterprise" (2006a. p. 11). The Supreme Court countered that the NCAA's conception of amateurism has changed steadily over the years, and quoted the lower court's finding that the NCAA "nowhere define[s] the nature of the amateurism they claim consumers insist upon." That court had "struggled to ascertain for itself 'any coherent definition' of the term, and even a former 
SEC commissioner testified that he had "never been clear on ... what is really meant by amateurism" (NCAA v. Alston, 2021, pp. 10-11). On the face of it, and in most dictionary definitions, the term 'amateur' refers to anyone who engages in an activity without being paid; it can also refer to someone who is incompetent or inept. That second meaning hardly applies to college athletes, who in many sports perform close to, often at, and sometimes above a professional level. What keeps them from being professionals according to the dictionary definition is that sport is not their "main paid occupation."

The NCAA's conception of amateurism, considered closely, emphasizes the idea of priority and does not exclude the possibility of payment. After all, many student-athletes already receive valuable compensation linked to their participation in sport. What the NCAA really wants to preserve is the idea that they are students first. In an article titled "Pay for Play is Fine_-But Not in College Sports," Brand distinguished the collegiate from the professional model of sport not upon whether athletes were paid, but rather upon the ends of the enterprise:

For the professional model, the bottom line is . . well . . the bottom line. For the collegiate model, the bottom line is education. In the professional model, the athletes are commodities who can be traded to meet market needs. In the collegiate model, the athletes are students (Brand, 2008, p. 1). Like Pythagoras' student in the initial phase, they are "paid" to be students and not to play sports. Playing sports is one part of the larger program of higher education that constitutes their main occupation during those years. Student-athletes are amateurs in the NCAA's view because their "end" while in college is supposed to be education, whereas a professional's "end" is supposed to be money. The heart of the matter is not dollars and cents, but rather means and ends.

The concept of amateurism has its philosophical roots in the idea that the moral value of an action depends partly on the end (telos) for which it is performed. The term 'amateurism,' based on the Latin word for love, suggests doing something for love rather than some external reward. Amateurism in sport emerged around the turn of the $20^{\text {th }}$ century - a period that witnessed the revival of the Olympic Games in Europe as well as the emergence of college sports in the United States. In those days, it was bound up with distinctions of social class - specifically a working versus a leisure class, ${ }^{3}$ but it was inspired by the ancient Greek idea that doing something for its own sake was always more noble than doing it for some external end. Aristotle identified this as the key characteristic of kalokagathia (beautiful goodness), an elevated moral status associated with both aristocracy and athletics. ${ }^{4}$ The so-called "Crown Games," in which winners received nothing more than wreaths of olive or laurel, were more prestigious than "money games" offering valuable prizes. The ancient Greek athletes who inspired the modern ideal of amateurism were certainly not amateur in the sense of being unpaid - nor did they all have a separate profession during their athletic careers. ${ }^{5}$ The point was that they engaged in sport as an end in itself rather than a means to some external end, thereby expressing their closeness to the gods - who have no needs and therefore do everything autotelically. ${ }^{6}$ Amateur- 
ism in this original context was not about payment or skill-level, but rather about attitudes and intentions, ends and means. Viewing sport as a means to external ends threatened the appreciation of its intrinsic value that amateurism sought to preserve (Morgan, 2020).

Restricting compensation has repeatedly proven itself a bad way to preserve the spirit of amateurism. Within the Olympic Movement, one might argue, the attempt to legislate amateurism paradoxically promoted love of money more than love of the game. ${ }^{7}$ There simply is no logical entailment between the fact that an athlete receives a cash prize or payment, and the idea that they are motivated by those things to play the sport. Apart from the reality that people have multiple motivations for acting, a person can engage in an activity for ends intrinsic to it even if the activity also serves external ends. Imagine I am cycling on the road from Siracusa to Sortino; this does not imply automatically that my "end" is to arrive at Sortino, perhaps I am training or riding for pleasure. As long as the benefits I seek are internal to the activity, one can say that I am doing it for its own sake — as an 'amateur'. The external fact that I am paid, or even categorized as a professional does not prevent me from being amateur in this sense. Indeed, current usage of the term 'professional' better describes the attitude expected of an amateur athlete. Whereas we generally use the term 'job' to describe something done strictly "for the money," we reserve the term 'profession' for activities placed at the center of our identities and our lives. A professional acts professionally because it is who she is and what she does.

Professions typically demand specialized education and long apprenticeships, and when people enter a profession like law or medicine or academia they become part of a group of highly-trained specialists who seek to preserve the quality of their common activity by holding each other to high standards. Professionals are paid (often handsomely) for their work, but in contrast with mere 'jobs,' that payment is not the only_ or even the central—end of their work. Indeed, lawyers working pro bono or a doctor volunteering to treat children in a war zone hardly cease to be professionals when they work without pay. If anything, such actions are considered more professional than their compensated work, and in some industries unpaid services are specifically referred to as 'professional courtesies' or 'professional obligations.' The idea of the consummate professional is one who has achieved such excellence in and dedication to her field that she embodies its ideals and can be relied upon to act in accordance with them without consideration for external rewards. Paradoxically, the presence of professional athletes competing for joy of it at the Olympic Games creates a better spectacle of amateurism than excluding them ever did (Reid, 2016). The amateurism that the NCAA is promoting better resembles this attitude than one characterized by ineptness or recreation. Likewise, it should be understood in terms of philosophical questions about attitudes and ends, rather than financial questions about money. Professionalism as an attitude is something that should be promoted by college sport, just as it is promoted elsewhere in higher education. What the NCAA wants to discourage is playing college sports as a job, strictly in exchange for wages. 


\section{Academics vs. Athletics}

We may even go so far as to say that colleges should promote a "professional" attitude toward sport, but not in the sense that students should be professional athletes (or, for that matter, "professional students"). ${ }^{8}$ Rather, college sports should promote the educational end of cultivating professional dispositions. It is no secret that the goal of most college and university students, athletes or not, is to become a professional rather than simply have a job. They go to college to receive the education necessary, not only the specialized knowledge, but also the generalized skills and appropriate dispositions for someone who aims to achieve excellence in their field. Indeed, the term 'liberal arts' - sometimes used derisively to describe subjects in the arts and humanities that seem detached from specific careers - may well derive from the idea of a "liberal professional" who can freely offer his or her expert services to clients independent of an institutional employer. The term is still used in Europe to classify lawyers, accountants, psychologists, architects, and other professionals who work for themselves. Given that learning to be professional is central to the enterprise of higher education, the NCAA's insistence on amateurism in athletics may seem paradoxical. But this is because the popular idea of college athletes being amateur because they are "students first" contains the pernicious assumption that one cannot be a student of sport.

To his credit, Brand recognized and defended the educational value of sport. In the 2006 State of the Association Speech, he even described it in language that reflects my argument about sport cultivating professional dispositions:

Since the participants in college sports are students-individuals whose first order of business is acquiring an education - their academic success is of central importance. You have all heard our refrain, 'There are more than 360,000 student-athletes, and almost all of them will go pro in something other than sports.' Those who participate in our games are the future doctors, lawyers, teachers, business people and elected officials. They are future family members and community leaders. A few will play professional sports; but they, too, should receive an education from our fine universities and colleges. The fact of the matter is that a college education is the best preparation for a successful, fulfilling, happy life, and acquiring that education should be primary. (Brand 2006a, p. 3)

Brand does not defend college sport as a training program for professional athletes; it would be a mistake to do so. Though some student-athletes attend college with precisely that goal in mind, the placement rate is just too low to count intercollegiate athletics as a pre-professional program - even in the powerhouse programs. Instead, Brand touts the educational value of sport for the professional and community roles traditionally adopted by college graduates. The mistake that some people make when hearing such statements is that they exclude sport from ideas such as "acquiring education" and "academic success." 
Conceptually opposing athletics and academics is understandable, of course. Faculties and universities tend to do the same - as evidenced by the fact that sports participation usually does not contribute toward earning a degree. College education is associated exclusively with academic activities, a category from which athletics is excluded even though the term 'academic' derives from Plato's gymnasium. In an article entitled "The Role and Value of Intercollegiate Athletics in Universities" (2006b), Brand pushes back against such misconceptions, arguing not only that intercollegiate athletics contributes to the "academic enterprise," but also that it could contribute far more if it was not regarded as a strictly extracurricular activity. His argument is based on a comparison with academic programs in the performing arts such as music, dance, and drama. Locating the bias against sports in a disdain for the body and physical skills in favor of the mind and cognitive skills, Brand suggests that performing arts, despite being physical skills, are accepted as academic because of their link with high culture (2006b, p. 14). This certainly is not the first time that social elitism and mind-body dualism rear their ugly heads in the debate about amateurism and the value of sport. I wonder, however, if Brand's argument based on physical skills falls short in describing the educational potential of sport.

The joke that "he went to college but majored in football" only works because sport is assumed to be separate and even a distraction from intellectual education. Majors in the performing arts are accepted also because they incorporate the academic study of theory, history, and other traditional subjects. Perhaps football could be a legitimate major too if it included courses in philosophy, physiology, and psychology. But the particular educational value of performance itself needs to be acknowledged and understood. Sports and performing arts at the collegiate level demand more than physical skill, they also engage high-level cognitive abilities and uncommon character virtues. Achieving excellence in almost any performed activity, even "intellectual" activities such as speaking a foreign language, requires consistent practice, persistence in the face of failure, and effective interaction with others. Likewise, almost every profession pursued in higher education, from law to medicine to accounting, demands not only specialized knowledge and career-specific skills, but also the ability to transform those things into a service performed for a client. In other words, professionalism is itself performance-excellent performance; and activities like sport, dance, drama, and music can teach us how to achieve it.

Excellent performance, moreover, characteristically demands the integration of mind and body; the harmonizing of cognitive and physical skills. Whether in music, drama, dance, or sport, it defies the epistemological distinction between knowing how and knowing that. ${ }^{9}$ It is, in contrast with many educational activities - especially traditional academics - essentially holistic. ${ }^{10}$ College sport is also holistic in the social sense. Student-athletes form what might be termed "performance communities," in which the pursuit of excellence in a common practice is cooperatively pursued by a group of like-minded practitioners. ${ }^{11}$ It does not matter whether the sport is team or individual - the bonding between members of a track team can be just as great as that of a basketball team. Performance communities may even include competitors from other schools and athletes from different sports; the common denominator, the 
basis for mutual understanding, is the shared commitment to excellence. It is no coincidence that professionalism is also associated with communities - specifically professional guilds and organizations such as the American Bar Association, which work to preserve the quality and integrity of the practice. No one denies that the knowledge required for particular careers is properly part of higher education, but the generalized skills and dispositions needed to perform as a professional are just as important. Because sport is an activity in which excellence can be reached at a fairly young age - indeed, the age normally devoted to higher education - it can be a great place to learn the process of pursuing of excellence as a way of life.

\section{Employment vs. Exploitation}

This performance-based argument for the educational value of high-performance sport may justify a young adult's athletic commitments, but does it justify athletic professionalism within universities? Elsewhere in the world, it is not uncommon for university students also to play professional sports. Italy's national soccer team includes several part-time students, including a star on its Euro 2020 team, Matteo Pessina, who is pursuing a degree in economics at a prestigious university (Currò, 2021). Tour de France cyclist Guillaume Martin earned a master's degree in philosophy while competing at the elite level. There is no law preventing professional athletes in America from enrolling in college, but few do because the demands of pro sports are hard to reconcile with serious study during the brief period of youth traditionally devoted to both. In other words, the dilemma for young elite athletes who also want to study is pretty much the same whether they play professionally or in college. Even if defenders of college sport can make a good educational argument for keeping elite sport and elite education under a single roof, so to speak, they still face the question of whether doing so amounts to athlete exploitation. The ethical issue for institutions is not about whether student-athletes should receive compensation - they already do - it is about what constitutes fair compensation in a given situation. ${ }^{12}$

Brand's arguments for amateurism in college sport were guided by the principle that it is embedded within colleges and universities, whose mission is education. "The participants in intercollegiate athletics are students," he said in his State of the Association Address. "They are not, in their roles as athletes, employees of the university. They are students who participate in athletics as part of their educational experience. This is the heart of the enterprise" (2006a, p. 5). The reminder is aimed especially at colleges and universities that fail to support and sometimes even obstruct the educational aspirations of their athletes. But even institutions that put education first may unethically and illegally exploit student-athletes by benefitting disproportionately or unfairly from that relationship. Brand (2008) points out that the revenue generated by a few high-profile sports goes to subsidize college athletics programs for the vast majority of student-athletes, in other words the money serves educational ends. "But somehow," he complains, "the obvious and even noble acquiring of money to finance the mission of higher education is characterized as little 
more than a ravenous greed for filthy lucre when it comes to financing the mission of intercollegiate athletics." As we said before, Brand does not deny that college sport is a business, he argues that it's a different kind of business than professional sport since its goal is not profit but rather to "to meet the mission of higher education"(Brand, 2008, pp. 1-2). But does subsidizing educational ends for the many justify the restrictions on compensation for the revenue-generating few? What sort of compensation is appropriate? Would exploitation concerns be resolved by making student-athletes employees of their colleges?

It makes sense, given that the relationship between students and colleges serves the end of education, to compensate students in educational terms. Remember that the Alston case struck down limits on education-related benefits (such as graduate tuition and paid internships) for student-athletes. If the educational value of athletics were better recognized, perhaps grants and fellowships sponsored by corporations or professional teams could be offered. ${ }^{13}$ Other legal decisions have struck down restrictions on what student-athletes can earn from outside sources, for example by selling the rights to their name, image, and likeness - a form of compensation that poses no direct threat to the priority of education in college sports, and may even provide student-athletes with the chance to learn about the business side of sports. Nor is it in question that institutions should use the revenue generated by sport to serve educational ends, but there are several professionals, including coaches and fundraisers, who earn handsome salaries while serving the educational ends of the institution. There are also several students who are employed as tutors, instructors, laboratory assistants, and more. What makes student-athletes different? In a concurring opinion on the Alston case, Justice Kavanaugh characterizes that relationship between colleges and student-athletes as one between business and labor. "The bottom line," he says, "is that the NCAA and its member colleges are suppressing the pay of student-athletes who collectively generate billions of dollars in revenues for colleges" (NCAA v. Alston, 2021, p. 4). He goes on to compare student-athletes to skilled workers such as cooks and camera crews, as well as college-educated professionals such as nurses, lawyers, and journalists. Is this how we should think about student-athletes, as labor whose wages have been suppressed by price-fixing agreements among their employers?

How we think about the relationship is crucial - for institutions, students, and spectators alike-because it conditions the ethical expectations of the parties. Some people argue that student-athletes should be treated as employees of the institution and offered the attendant benefits. This would clearly change what counts as fair within the relationship. As a professor, my relationship with students in my classes was clearly different from my relationship with students hired to work in our officeeven when it concerned the same person. It was fair, for example, to ask a student in her role as office worker to type up a document for me or even to run to the library for me because these tasks were part of a job for which she was compensated by wages. It would have been inappropriate to assign her such tasks in my class, however, because they do not directly serve her educational ends. Different relationships call for different expectations and compensations. Insofar as the relationship between institutions and student-athletes is aimed at their education, like the relationship be- 
tween professors and students (and, ideally the relationship between coaches and athletes), it imposes restraints on what should be asked of them and what ends those tasks should serve. If the relationship were one of employment, by contrast, workers may legitimately be asked to serve the institution's interests on the understanding that such service will be compensated by wages.

Supporters of the employment solution might counter that student-athletes already are treated like workers in a business rather than students in a classroom. Indeed, it can be plausibly argued that the financial benefits of college sports - in contrast with the performing arts - make the educational exploitation of student-athletes all but inevitable. But this practical approach overlooks serious ethical questions that cannot be addressed by wages or benefits. An institution that uses student-athlete "labor" to generate revenue - whether or not it fails to compensate them with a share of that revenue, and whether or not it conspires with other institutions to prevent a competitive market for their labor - is violating the means-end principle that governs the ethics of educational relationships. This violation is actually deeper and wider than the economic exploitation of the small percentage of athletes who actually generate revenue in college sport. As Brand points out, "The idea that a market should be created for the employment of students to play sports because it is only fair would benefit only a few individuals in only a couple of sports on only a handful of campuses where revenues exceed expenses" (Brand, 2008, p. 2). Employing the few student-athletes who actually generate revenue - even paying them handsome salaries with benefits - will not resolve the perception of the many that their colleges are exploiting them. And this perception is widespread, even among those receiving scholarships to play sports that do not generate revenue and have no professional leagues. Perhaps these student-athletes sense an ethical violation in their educational relationship with their colleges, or perhaps they already view themselves as exploited employees. In either case, this situation is educationally tragic because colleges teach ethics most effectively through their treatment (or mistreatment) of students (Bok, 1995). The relationship between student-athletes and their colleges needs to be one in which both parties receive the appropriate benefits. ${ }^{14}$ It is hard to imagine that transforming an unsatisfactory educational relationship into an employment relationship will resolve the issue of exploitation in college sports. Employees are just as capable of being exploited by institutions as students are.

All of this is not to say that the problem is simply the students' failure to appreciate the educational nature of their relationship with colleges and the intrinsic value of their sports experience. Colleges are just as guilty of abusing the relationshipmaybe more so since they dictate the terms. Those who criticize college recruits for seeking better compensation forget that most students are financially motivated to attend college. A college education is understood and even promoted as a means to the end of increased lifetime earnings, and athletic recruiting is no exception. In fact, the presentation and promotion of athletic programs as businesses rather than educational programs only perpetuates the pernicious idea that money is what really counts in higher education overall. We can hardly blame young people in this environment for discounting the educational aspects of college as well. As noted above, the relationship between colleges and students is educational for better or for worse. 
When colleges use athletes as means to financial ends, the lesson they teach is that it is acceptable to treat others as means to selfish ends - no matter how often Immanuel Kant's moral injunction against this is repeated in the classroom. ${ }^{15}$ Employment and exploitation are not opposites. What is needed to avoid exploitation in college sport is fair compensation that serves the end of education - as the ethics of college-student relationships clearly demands.

\section{Conclusion}

Students who go to college hoping to become professional athletes are not really that different from their classmates. They are looking to make a career out of something they love to do by becoming excellent at it. When students ask me for advice on a career in philosophy, I tell them they have to do it out of love. They have to be willing to put the time and effort into earning a Ph.D. without any expectation of becoming a professor; if they love philosophy that much then they may become good enough at it to make a living doing it. In other words, you need to be an amateur in order to become a professional. But professional careers in philosophy are just too rare to be the reason for studying it. This is true of many, if not most of the subjects studied in college. They do not train students for a particular job, they construct the framework of skills and dispositions upon which professional careers are built. College sport can and does contribute to that end, especially insofar as it teaches us to transform our love for an activity into excellence. It is and should remain amateur in that sense, as part of an education aimed at professionalism.

This essay has explored the value of college sport by interrogating three apparent oppositions: amateurism vs. professionalism, academics vs. athletics, and employment vs. exploitation. As Brand recognized, education is the end that resolves college sport's paradoxes. The ideal of amateurism focuses on means and ends, privileging things done for their intrinsic value, i.e. as ends in themselves. Engaging in the pursuit of excellence through elite-level sport, furthermore, has the potential to generate performance virtues that are as important for professional careers as traditional academic subjects. In terms of disposition, amateurism and professionalism turn out to be more similar than different. Restrictions on compensation consistently fail to promote the amateur spirit, however. Avoiding exploitation in the educational relationship between colleges and students is a question of fairness, not finance. If colleges would recognize and promote the educational value of elite athletics, student-athletes more likely would, too. Once both parties recognize that the end of their relationship is education, they should be able to negotiate fair and appropriate compensation. In any case, we should not assume that student-athletes put a dollar sign before their answer to the question, "What is the value of college sport?" Said top basketball prospect Jalen Duren about the recruiting process, "It's never been and never will be about money. I just want to get better, and I love the game too much to cheat it that way" (quoted in Witz, 2021, p. 7). No more "amateur" approach to college sport can be imagined - whether he gets paid or not. 


\section{Notes}

1. Plato, Republic, $410 \mathrm{bc}$. For a complete account of Plato's use of sport in education, see Reid (2007) and Reid (2011), pp. 56-68.

2. There is also an interesting educational story behind the term 'athletics,' which has its root in the athla (feats, labors) of heroes like Heracles. See Reid (2019).

3. As Llewellyn and Gleaves (2016, pp. 6-7), put it, "The social origins of amateurism sprung to life ... from Victorian Britain, where an upper-middle-class (and to a far lesser degree, aristocratic) desire to set themselves apart from the perceived morally corrupt working classes employed amateurism as a legitimating ideology for elitist sporting preserves. Amateurism represented a tool for those who held power to reassert control in times of social disorder and political subversion." For a philosophical analysis of $19^{\text {th }}$ century amateurism, see Morgan (2020), especially Chapter 1.

4. The most complete account is in Eudemian Ethics 8.15. For a discussion of the concept applied to Olympic Sport, see Reid (2020, pp. 195-203) and Reid (2021, pp. 222-224).

5. Elite athletes in ancient Greece often made a living from their winnings and Olympic victors sometimes received state support for life. For an overview see Young $(1984,1988)$.

6. One might argue that this was a religious end, which could be understood economically as favor from the gods in things like bountiful harvests (Reid, 2020), but the added religious prestige of competing for the crown was linked specifically to the fact that it served no immediate personal need.

7. This argument is made in several essays in Reid (2020); see especially pp. 104-106; 213-216; 390-391.

8. The term "professional student" is usually applied jokingly to people who stay in school long past the normal time needed to graduate, or, if they graduate, they continue to pursue additional degrees rather than transitioning into the world of employment.

9. This distinction between ways of knowing was brought to light by Ryle (1949). The question of how and whether it applies to skilled action has been debated extensively in recent years; for an overview, see Fridland and Pavese (2020).

10. Sport philosopher Jesus Ilundain-Agurruza has investigated the cultivation of excellence in performance, a process he calls "Skillful Striving." He notes that in athletics, martial and performing arts, "latent skills flourish and weaknesses can be made assets by nurturing intellectual, physical, emotional, and social abilities through disciplined movement, purposeful reflection, and emotional control" (2016, p. 2). The process involves moving and acting as what he calls "holistic, integrative bodyminds," and it brings together more than the body and the mind. The pursuit of performative excellence connects skills with virtues and ethics with aesthetics because (1) doing your best is moral, (2) skill is beautiful, (3) virtues improve skills, and (4) skill is community based (Ilundain-Agurruza, 2017, p. 331). 
11. My idea of performance communities is based on Alasdair MacIntyre's (1981) social practice theory, which provides the modern framework for linking sport with virtue cultivation, and Ilundain-Agurruza's emphasis on the communal nature of skillful striving. "Laudable character," he says, "is built on discipline, responsibility, and a social framework that provides personal paradigms and standards of excellence" (2016, p. 1).

12. Zema (2019) argues that colleges and universities are not obligated to compensate athletes beyond tuition, room, and board, but student-athletes should be free to receive external compensation.

13. Corlett (2013) argues that colleges and universities are themselves exploited economically by professional sports franchises who use them to train their players.

14. Otto and Otto (2013), for example, propose a "distribution fairness model" which includes, among other things, insurance to cover future losses in case of injury and a derivative-value trust to permit the student-athlete to share in profits derived from his or her fame.

15. The injunction to always treat others as ends in themselves is the second formulation of Immanuel Kant's (1795/1983) famous "categorical imperative," commonly taught in introductory ethics courses.

\section{References}

Bok, D. (1996). Can higher education foster higher morals? In W. H. Shaw (Ed.), Social and personal ethics (pp. 493-503). Wadsworth.

Brand, M. (2006a, Jan. 7). The principles of intercollegiate athletics [State of the Association speech] NCAA Convention, Indianapolis, IN. https://mylesbrand.com/

Brand, M. (2006b). The role and value of intercollegiate athletics in universities. Journal of the Philosophy of Sport, 33(1), 9-20. https://mylesbrand.com/

Brand, M. (2008, August 20). Pay for play is fine-but not in college sports. The Huffington Post.

Corlett, J. A. (2013). Economic exploitation in intercollegiate athletics. Sport, Ethics and Philosophy, 7(3), 295-312.

Currò, E. (2021, June 29). Matteo Pessina, lo studente goleador che voleva smettere. La Reppublica.

Fridland, E., \& Pavese, C. (Eds.). (2020). The Routledge handbook of philosophy of skill and expertise. Routledge.

Iamblichus (1818). The Pythagorean life (Thomas Taylor, Trans). Watkins. (Original work published ca. $300 \mathrm{CE}$ ).

Ilundain-Agurruza, J. (2016). Holism and the cultivation of excellence in sports and performance: Skillful striving. Taylor and Francis.

Ilundain-Agurruza, J. (2017). A different way to play: Holistic sporting experiences. In R. Scott Kretchmar (Ed.). Philosophy: Sports (pp. 310-343). MacMillan.

Kant, I. (1983). Groundwork for a metaphysics of morals. Translated by Ted Humphrey. Hackett. (Original work published in 1795). 
Llewellyn, M.P., \& Gleaves, J. (2016). The rise and fall of Olympic amateurism. University of Illinois Press.

MacIntyre, A. (1981). After virtue. University of Notre Dame Press.

Morgan, W.J. (2020). Sport and moral conflict. Temple University Press.

NCAA v. Alston, 594 U.S. (2021). https://www.supremecourt.gov/opinionS/20pdf/20-512 gfbh.pdf.

Otto, K.A., \& Otto, H.R. (2013). Clarifying amateurism: A logical approach to resolving the exploitation of college athletes dilemma. Sport, Ethics and Philosophy, 7(2), 259-270.

Reid, H.L. (2007). Sport as moral education in Plato's Republic. Journal of the Philosophy of Sport 34(2), 160-175.

Reid, H.L. (2011). Athletics and philosophy in the ancient world: Contests of virtue. Routledge/Taylor \& Francis.

Reid, H.L. (2016). Amateurism is dead: Long live amateurism. In D. Chatziefstathiou, X. Ramon, \& A. Miragaya (Eds.), The Olympic idea nowadays (pp. 6163). Centre d'Estudis Olímpics.

Reid, H.L. (2019). Heroic Mimēsis and the ancient Greek athletic spirit. CHS Research Bulletin 7. http://nrs.harvard.edu/urn-3:hlnc.essay:ReidH.Heroic Mimesis and the Ancient Greek Athletic Spirit.2019

Reid, H.L. (2020). Olympic philosophy: The ideas and ideals behind the ancient and modern Olympic Games. Parnassos Press.

Reid, H.L. (2021). Aristotle on the beauty of fair play. Estetica. Studi e Ricerche, 9(1), 217-226.

Ryle, G. (1949). The concept of mind. University of Chicago Press.

Witz, B. (2021, June 28). The dynamics of college sports are changing. The International New York Times.

Young, D.C. (1984). The Olympic myth of Greek amateur athletics. Ares.

Young, D.C. (1988). How the amateurs won the Olympics. In W. Raschke (Ed). The archaeology of the Olympics (pp. 55-78). University of Wisconsin Press.

Zema, P. (2019). Should student-athletes be paid? Sport, Ethics and Philosophy, 13(2), 198-212. 